\title{
Comparison Global Brain Volume Ratios on Alzheimer's Disease Using 3D T1 Weighted MR Images
}

\author{
Muhammet Üsame Öziç ${ }^{1 *}$, Seral Özşen ${ }^{2}$ \\ ${ }^{1}$ Necmettin Erbakan University, Faculty of Engineering and Architecture, Department of Biomedical Engineering, Konya, Turkey (ORCID: 0000-0002-3037-2687) \\ ${ }^{2}$ Konya Technical University, Faculty of Engineering and Natural Science, Department of Electrical-Electronics Enginnering, Konya, Turkey (ORCID: 0000-0001- \\ 5332-8665)
}

(İlk Geliş Tarihi 3 Şubat 2020 ve Kabul Tarihi 17 Mart 2020)

(DOI: 10.31590/ejosat.697446)

ATIF/REFERENCE: Öziç, M. Ü. \& Özşen, S. (2020). Comparison Global Brain Volume Ratios on Alzheimer's Disease Using 3D T1 Weighted MR Images. Avrupa Bilim ve Teknoloji Dergisi, (18), 599-606.

\begin{abstract}
Alzheimer's Disease is a cause of dementia that starts with the loss of cognitive functions. The degeneration that starts in memoryrelated areas in the brain spreads to other regions as the disease progresses. Volumetric losses occurring in the brain can be monitored with high resolution 3D T1-weighted magnetic resonance images. The interpretation of these images is carried out by radiologists in hospitals. However, since the voxel intensity transitions of the brain regions are not clear in magnetic resonance images, computeraided numerical methods are needed. These methods can perform pre-processing, post-processing, segmentation and volume calculation on magnetic resonance images. In this study, gray matter, white matter, cerebrospinal fluid, total intracranial volume, parenchyma, and lateral ventricle global volumes were calculated for 70 Alzheimer Patients and 70 Normal Control 3D T1-weighted magnetic resonance images taken from Open Access Series of Imaging Studies database. SPM8 and MRIcro programs, ALVIN and VBM8 libraries were used. Since the numerical methods used are found in different programs and libraries, a model is proposed which combinations should be used. Volumetric results are relative due to the different head sizes in each person. Therefore, the problem of relativity should be eliminated by proportioning each volume value with another volume value. Twenty different metrics of the brain were obtained by summing and dividing the six global volume regions obtained in different combinations. Using these values, it was determined whether there was a statistically significant difference between two groups by independent samples t-test. The performance of the numerical methods and the statistical results of twenty metrics obtained from global brain volumes were discussed. After measurements and evaluations, it was observed that the ratio of cerebrospinal fluid volume to gray matter volume was an important marker in the differential diagnosis of the disease.
\end{abstract}

\section{B T1 Ă̆ırlıklı MR Görüntüleri Kullanarak Alzheimer Hastalığına İlişkin Global Beyin Hacim Oranlarının Karşılaştırılması}

$\ddot{O} z$

Alzheimer Hastalığı bilişsel fonksiyonların kaybı ile başlayan bir demans nedenidir. Beyinde hafiza ile ilgili bölgelerde başlayan dejenerasyon hastalık ilerledikçe diğer bölgelere yayılmaktadır. Beyinde meydana gelen hacimsel kayıplar yüksek çözünürlüklü 3B T1 ağırlıklı manyetik rezonans görüntüleri ile izlenebilmektedir. Bu görüntülerin yorumlanması hastanelerde radyologlar tarafından gerçekleştirilmektedir. Ancak manyetik rezonans görüntülerinde beyin bölgelerinin voksel intensite geçişleri net olmadığından bilgisayar destekli sayısal yöntemlere ihtiyaç duyulmaktadır. Bu yöntemler manyetik rezonans görüntüleri üzerinde önişleme, son işleme, segmentasyon ve hacim hesaplama yapabilmektedir. Bu çalışmada Open Access Series of Imaging Studies veri tabanından alınan 70 Alzheimer Hasta 70 Normal Kontrol 3B T1 ağırlıklı manyetik rezonans görüntüleri üzerinde bilgisayar destekli sayısal yöntemler kullanılarak gri madde, beyaz madde, beyin omurilik sıvısı, total beyin hacmi, parankima ve lateral ventrikül bölgelerinin hacimleri hesaplanmıştır. Çalışmada SPM8 ve MRIcro programları , ALVIN ve VBM8 kütüphaneleri kullanılmıştır. Kullanılan sayısal yöntemler farklı program ve kütüphaneler de bulundukları için hangi kombinasyonda kullanılmaları gerektiğini gösteren bir model

\footnotetext{
* Sorumlu Yazar: Necmettin Erbakan University, Faculty of Engineering and Architecture, Department of Biomedical Engineering, Konya, Turkey, ORCID: 0000-0002-3037-2687, muozic@gmail.com
} 
önerilmiştir. Her insanda kafa büyüklüğünün farklı olmasından dolayı hacimsel sonuçlar göreceli olmaktadır. Bundan dolayı her bir hacim değeri başka bir hacim değeri ile oranlanarak görecelik problemi ortadan kaldırılmalıdır. Elde edilen altı global hacim bölgesinin farklı kombinasyonlarda toplanması ve bölünmesi ile beyne ait yirmi farklı metrik elde edilmiştir. Bu değerler kullanılarak bağımsız örneklem t-testi ile iki grup arasında istatistiksel olarak anlamlı bir farklılık olup olmadığı belirlenmiştir. Kullanılan sayısal yöntemlerin performansı ve global beyin hacimlerinden elde edilen yirmi metriğin istatistiksel sonuçları tartışılmıştır. Ölçümler ve değerlendirmelerden sonra beyin omurilik sıvısı hacminin gri madde hacmine oranının hastalığın ayırıcı tanısında önemli bir işaretçi olduğu gözlemlenmiştir.

\section{Anahtar Kelimeler: Alzheimer, Hacim, Oran, SPM8, VBM8, MRI}

\section{Introduction}

Alzheimer's Disease (AD) is a neurological disorder that starts with aging and forgetfulness. It is not known why the disease started and there is no cure to stop it. If it can be diagnosed at an early stage, there are some treatments that extend the patient's AD stage for some time (Dubois et al., 2016). Approximately 50-70\% of the causes of dementia seen in the clinic are AD (Selekler, 2010). While the proportion of many common diseases is decreasing in the world, AD is increasing proportionally (Association, 2019). According to the Alzheimer's Association of Turkey, 600 thousand families in our country are struggling with AD (Derneği, 2020). $\mathrm{AD}$ begins with simple forgetfulness and volumetric losses occur in memory-related areas of the brain. These volume changes of the brain regions and their ratios to each other give information about the disease as a biomarker (Holland et al., 2009; Petropoulos, Sibbitt Jr, \& Brooks, 1999; Schuff et al., 2009; Villarreal et al., 2002). These biomarkers are extremely important in terms of diagnosis of the disease, early phase identification, long-term follow-up (G. B. Frisoni, Fox, Jack, Scheltens, \& Thompson, 2010; Vemuri \& Jack, 2010). 3D Magnetic Resonance (MR) imaging is a high-resolution medical imaging technique that shows rigid changes in the brain (G. B. Frisoni et al., 2010; Vemuri \& Jack, 2010). MR images consist of successive slices. Therefore, if a slice is being evaluated, the previous and next slice of that slice should also be evaluated together. 3D MR images are usually interpreted manually by radiologists. This interpretation gives specific information about the disease such as volumetric measurements, perimeters, segmentation, and the amount of atrophy. However, the results of the calculation of these variables may vary from experiment to experiment and give relative results. It is also time-consuming and capable of making mistakes (Keller \& Roberts, 2009). Since the voxel intensity transition between brain regions is not very clear in MR images, computer-aided digital systems that measure and segment regions automatically instead of manual interpretations could be an effective solution. With the increasing of numerical methods, automatic brain analysis programs are continuously being developed. Linux based Freesurfer (Fischl, 2012) and FSL (Jenkinson, Beckmann, Behrens, Woolrich, \& Smith, 2012), MATLAB based Statistical Parametric Mapping (SPM) (Ashburner et al., 2008) are frequently used in the literature. These programs can perform pre-processing, post-processing and segmentation operations on images using powerful algorithms.

The brain consists of three basic areas: gray matter (GM), white matter (WM), cerebrospinal fluid (CSF). GM is a region where functional centers are located. WM is the region where neurons are located under GM. The CSF is a fluid that protects the brain from outside interventions. Since AD starts with forgetfulness, volumetric losses occur primarily in the memory-related regions. Atrophy occurs especially in the hippocampus, amygdala, limbic system and temporal lobe areas on GM (Petrella, Coleman, \& Doraiswamy, 2003). It is stated that there are also some losses in the WM (Salat et al., 2009). As volumetric losses in GM and WM regions increase, the amount of CSF increases. The lateral ventricle (LV) in the middle of the brain enlarges, and this part is filled with CSF. As a result, GM, WM, CSF and LV volumes are the main global volume biomarkers for the disease. In this study, GM, WM, CSF and LV volume measurements were calculated by using packet programs on 3D T1-weighted Normal Control (NC) and AD MR images. 70 AD and 70 NC 3D T1-weighted MR images were taken from the Open Access Series of Imaging Studies (OASIS) database. MR images have been labeled with Clinical Dementia Rating (CDR) neuropsychological test. Using this test, some questions are asked to patients and their relatives. Thus, the stage of the disease is determined. CDR consists of five phases; CDR0 normal, CDR0.5 mild cognitive impairment, CDR1 early stage, CDR2 moderate stage, CDR3 heavy stage. There are data labeled between CDR0-CDR2 in the OASIS database. In Figure 1, a single slice of MR images labeled CDR0, CDR0.5, CDR1, CDR2 are given, respectively. As seen in Figure 1, as the stage progresses, the brain shrinks and volumetric losses increase (Öziç, 2018).

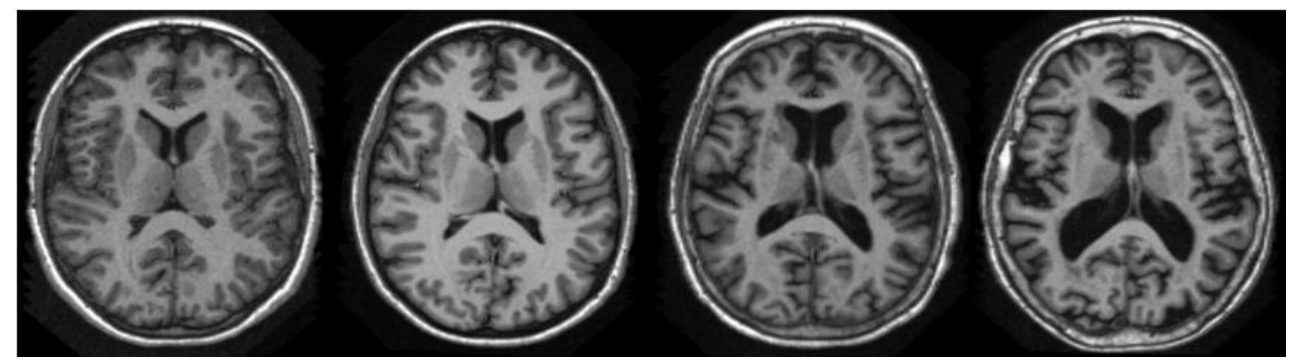

Figure 1: Single slice of MR images labeled CDRO, CDR0.5, CDR1, CDR2, respectively (Marcus et al., 2007)

MRIcro, SPM8, VBM8, ALVIN package programs were used in this study (Kempton et al., 2011; Kurth, Luders, \& Gaser, 2010; MRIcro, 2020; Penny, Friston, Ashburner, Kiebel, \& Nichols, 2011). ALVIN and VBM8 are an SPM8 plugin. MRICro is used for preprocessing and visualization. The programs used are not sufficient for volume calculation alone. The output of one program can be 
the input of another program. Therefore, in this study, a model regarding the order in which package programs and libraries can be used is also proposed. For the analysis of AD disease, a total of twenty metrics were derived, with different combinations of six global volume regions: GM, WM, CSF, LV, Total Intracranial Volume (TIV (GM+WM+CSF)), and Parenchyma (GM+WM). The measured values were analyzed with independent samples t-test. It was evaluated whether the values were significant or not.

\section{Material and Methods}

\subsection{Data Set}

$70 \mathrm{AD}$ and $70 \mathrm{NC}$ T1 weighted MR images were taken from the OASIS database. The OASIS database consists of MR images ranging in age from 18 to 96. The images are composed of young and old AD MR images. MR data are labeled with Mini Mental Status Test (MMSE) and Clinical Dementia Rating (CDR) neuropsychological tests. MMSE scoring ranges from 0-30, while CDR ranges from 0-3. The OASIS database contains only labeled CDR0-2. Therefore, images labeled CDR0 as NC, images labeled CDR0.5-2 were used as AD in this study. Since age 65 is a risk factor for AD, data above this age were taken from the database. Data set used and demographic distrubution are given in Table 1. There are MR images already pre-processed and registered to the Talairach axis in the database. However, these registered images do not represent actual volume values. Therefore, only the raw images prefixed with "OAS1_xxxx_MRy_mpr_ni_anon_sbj_111" were taken. The necessary pre-processing on the raw images have been performed in the study. OASIS database imaging protocols are TE:4.0 msec, TR:9.7 msec, TI: $20 \mathrm{msec}$, flip angle=10, 128 sagittal, 1.25 slice thickness without gap, pixel resolution 256x256 $(1 \mathrm{x} 1 \mathrm{~mm})$ and $\mathrm{T} 1$ weighted magnetization-prepared rapid gradient echo (MPRAGE) multiple high- resolution images via 1.5 T vision scanner (Siemens, Erlangen, Germany)(Marcus et al., 2007).

Table 1: Data set used in this study and demografic distrubution

\begin{tabular}{cccccc}
\hline \multicolumn{7}{c}{ NC } \\
\hline Age Gr. & Numb. & M\F & Mean Age & Mean MMSE & CDR \\
\hline $\mathbf{6 0 s}$ & 9 & 316 & $68.00 \pm 1.11$ & $28.77 \pm 1.64$ & 0 \\
$\mathbf{7 0 s}$ & 32 & 8124 & $73.37 \pm 2.44$ & $29.15 \pm 0.91$ & 0 \\
$\mathbf{8 0 s}$ & 22 & $6 \backslash 16$ & $83.40 \pm 3.27$ & $28.77 \pm 1.26$ & 0 \\
$\mathbf{9 0 s}$ & 7 & 116 & $91.14 \pm 1.67$ & $28.57 \pm 1.71$ & 0 \\
\hline Total & 70 & 18152 & $77.61 \pm 7.48$ & $28.92 \pm 1.21$ & 0 \\
\hline
\end{tabular}

\begin{tabular}{cccccc}
\hline \multicolumn{5}{c}{ AD } \\
\hline Age Gr. & Numb. & M\F & Mean Age & Mean MMSE & CDR \\
\hline $\mathbf{6 0 s}$ & 7 & $3 \backslash 4$ & $67.85 \pm 1.21$ & $23.42 \pm 4.85$ & $5 \backslash 2 \backslash 0$ \\
$\mathbf{7 0 s}$ & 35 & $14 \backslash 21$ & $74.42 \pm 2.61$ & $24.54 \pm 4.21$ & $23 \backslash 11 \backslash 1$ \\
$\mathbf{8 0 s}$ & 23 & $11 \backslash 12$ & $82.69 \pm 2.61$ & $24.47 \pm 4.06$ & $16 \backslash 6 \backslash 1$ \\
$\mathbf{9 0 s}$ & 5 & $2 \backslash 3$ & $92.00 \pm 2.44$ & $23.80 \pm 1.92$ & $4 \backslash 1 \backslash 0$ \\
\hline Total & 70 & $30 \backslash 40$ & $77.74 \pm 6.66$ & $24.35 \pm 4.05$ & $48 \backslash 20 \backslash 2$ \\
\hline
\end{tabular}

\subsection{Measurement of Global Brain Volumes}

To make volume analysis in 3D raw MR images, some pre-processing techniques must be done. Firstly, images were converted from the sagittal axis to axial axis with MRIcro program. Because the template images in VBM8 and SPM8 programs are defined on the axial axis, this process must be done. With the "Display" option of SPM8 program, a reorientation process was performed to the Anterior Commissure (AC) point. This point is considered to be the center point of the brain $(x, y, z=0)$ (Talaraich \& Tournoux, 1988). This process is called AC/Posterior Commissure (PC) line correction. Otherwise, the MATLAB program gives an error in the next steps. These data for the segmentation process were given to input of the VBM8 library. VBM8 library is an SPM8 plug-in that combines the preprocessing and segmentation stages of structural MR images. Using this plug-in, bias correction, denoising, normalization, and segmentation processes were performed automatically on the 3D structural MR images. The high-dimensional Diffeomorphic Anatomical Registration Through Exponentiated Lie Algebra (DARTEL) method was chosen for normalization to the Montreal Neurological Institute (MNI) space. The DARTEL method was proposed by John Ashburner (Ashburner, 2007). This normalization method gives the best register among 14 different normalization algorithms (Klein et al., 2009). It also gives the best register between MR images taken with different protocols from different centers (Goto et al., 2013). The Modulation method was preferred for segmentation. Modulation operation is an option that maintains the volume in the native space before normalization (Mechelli, Price, Friston, \& Ashburner, 2005). As a result of the processes, segments of GM, WM ,and CSF regions were obtained in Montreal Neurological Institue (MNI) space. Image volumes were calculated by using "get_totals.m" MATLAB script developed by Ged Ridgway (Ridgway, 2020). LV volume and segmentation were obtained with the ALVIN program over the modulated CSF images segmented with the SPM8 program (Kempton et al., 2011). The amount of TIV was calculated by summing up GM, WM and CSF volumes, and the Parenchyma (PRM) tissue volume was calculated by summing up GM and WM volumes. Thus, the volumes of six regions in total were calculated in milliliters $(\mathrm{ml})$. In Figure 2, a flow diagram that performs pre-processings on raw 3D T1weighted MR image of the subject numbered 430 from OASIS database and finding segmentation and volume values of GM, WM, CSF, LV, TIV, PRM regions are given. Three-dimensional models of four global brain regions are shown in Figure 3. In Figure 4, the borders of the GM, WM, CSF, PRM, TIV regions on the MR image and the LV region's borders on the modulated segmented GM are given. 


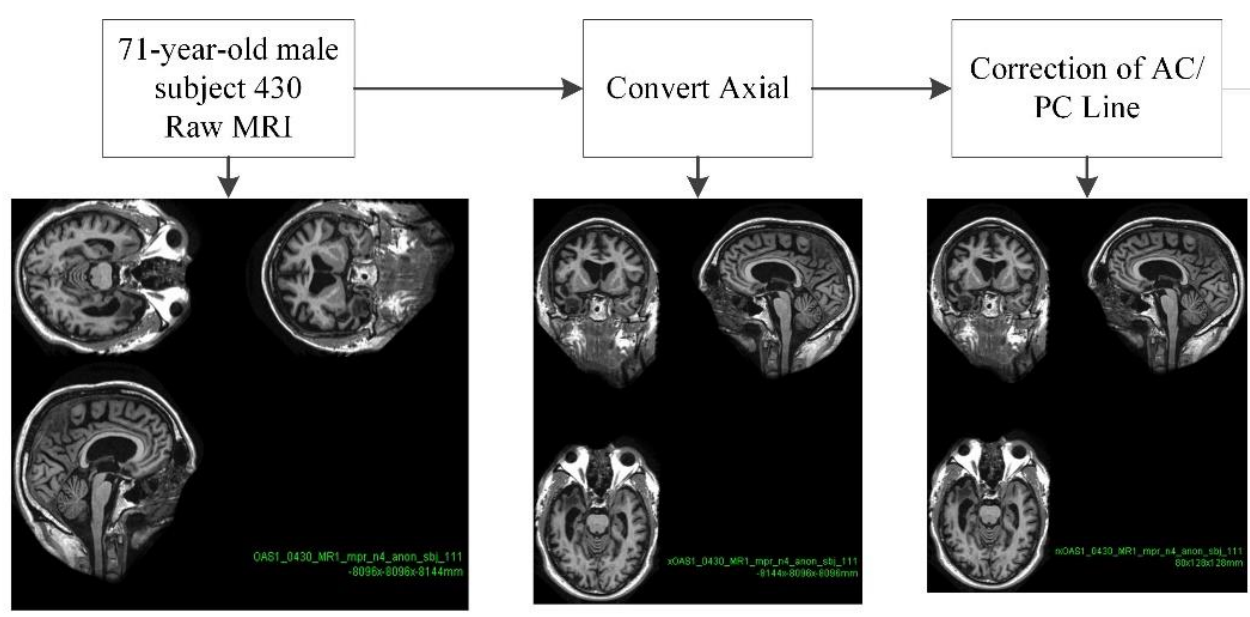

Bias Correction, Denoising, DARTEL Normalization,Modulated Segmentation with VBM8 Toolbox

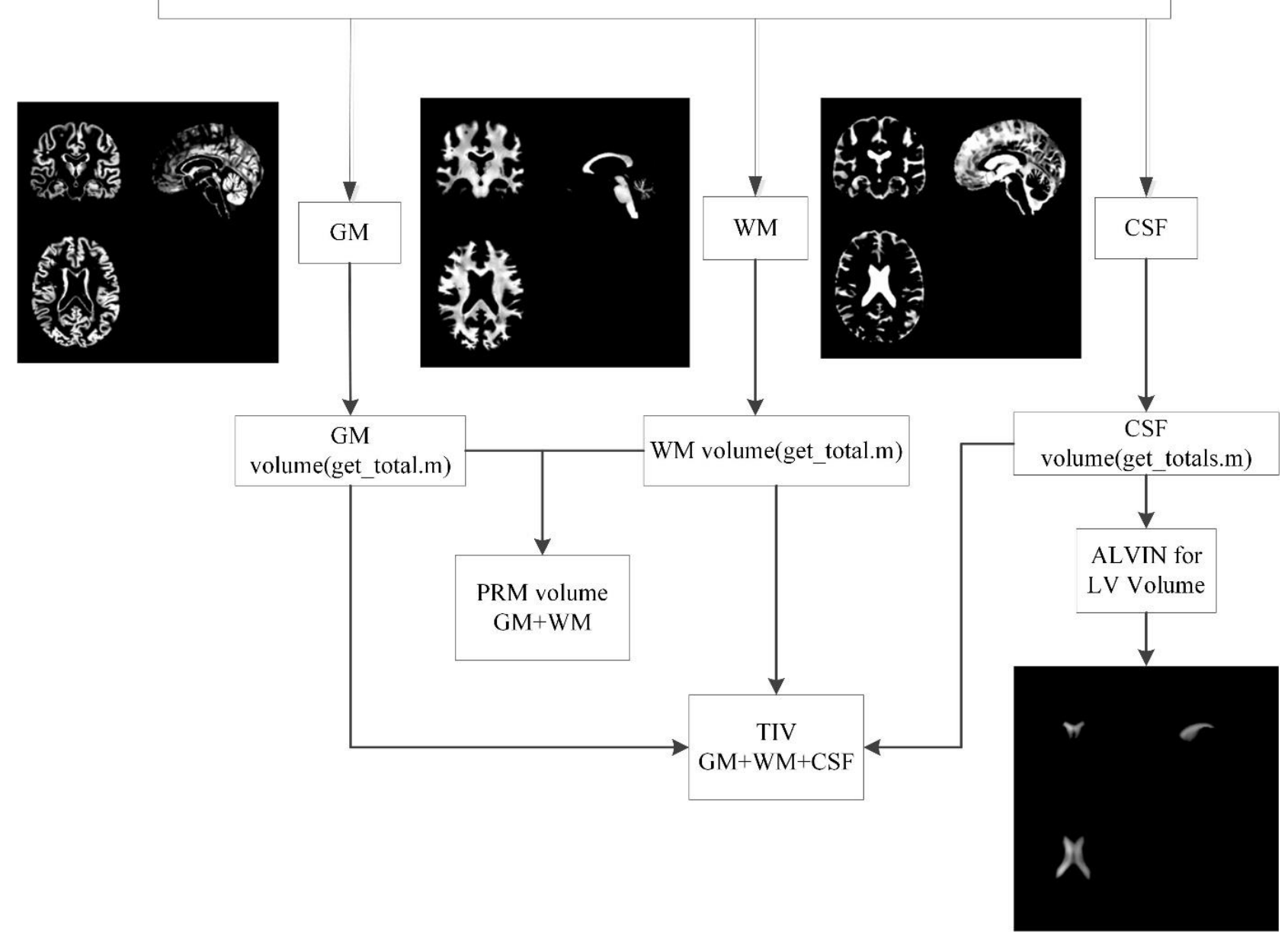

Figure 2. Flow diagram that performs pre-processings on raw 3D TI-weighted MR image of the subject numbered 430 from OASIS database and finding segmentation and volume values of GM, WM, CSF, LV, TIV, PRM regions (Öziç, 2018) 


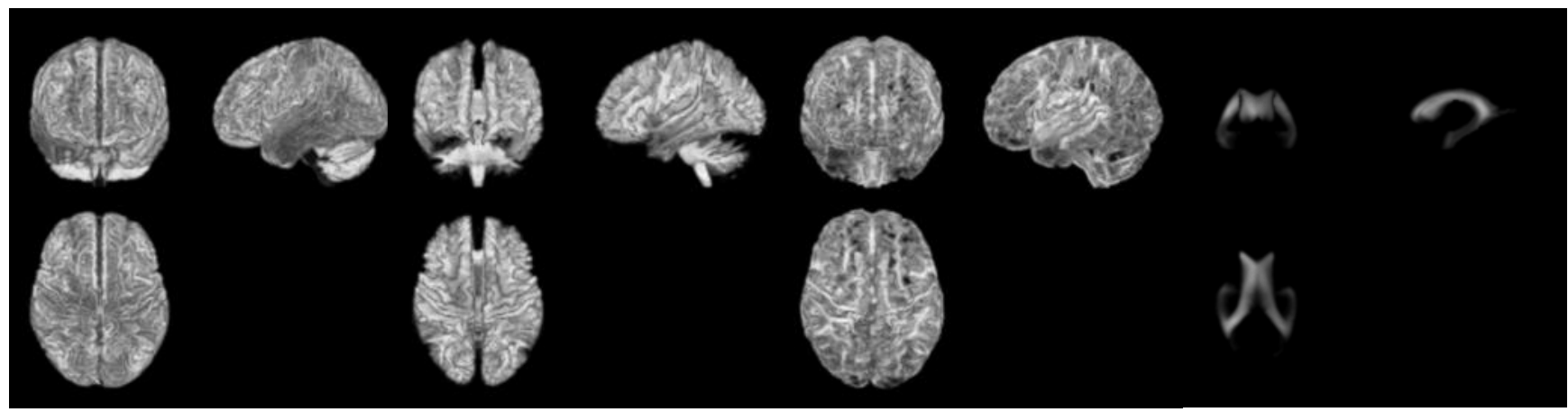

Figure 3. Three-dimensional models of four global brain regions (GM, WM, CSF, LV)

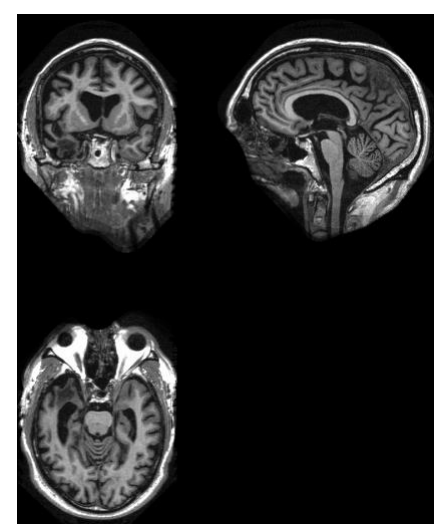

(a)

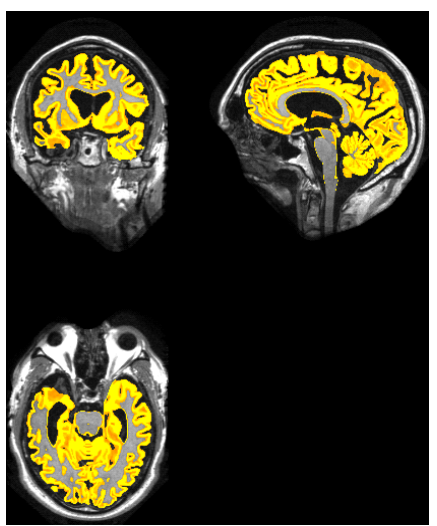

(b)

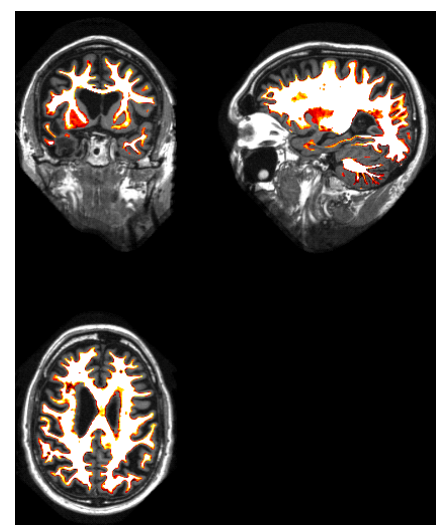

(c)

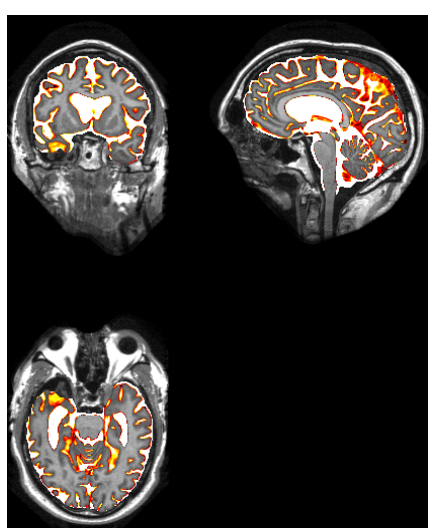

(d)

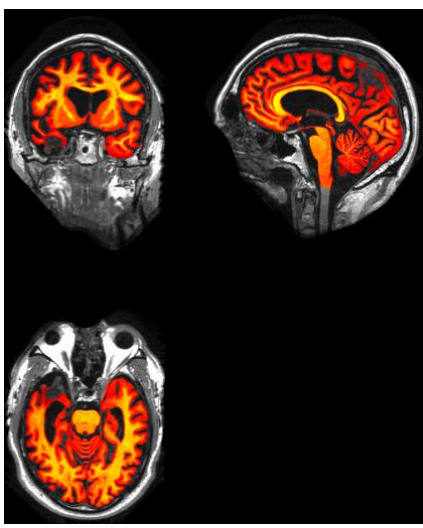

(e)

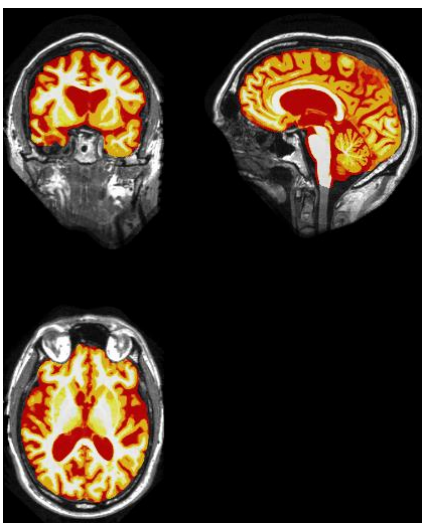

(f)

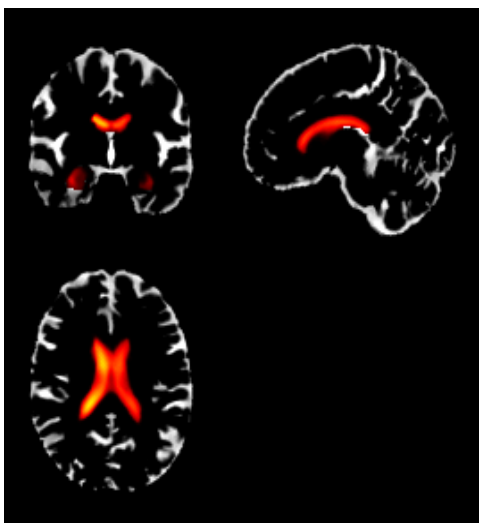

(g)

Figure 4. (a) Converted axial plane OASIS 430 raw MR image (b) GM borders on raw MR image (c) WM borders on raw MR image (d) CSF borders on raw MR image (e) Parenchyma borders on raw MR image (f) TIV borders on raw MR image ( $g$ ) LV borders on modulated segmented GM

\section{Research Results and Discussion}

GM, WM, CSF, PRM, TIV, LV volumes were obtained by using the flow diagram in Figure 2 in each T1-weighted 3D MR image. With the volumes of the six regions obtained, twenty-six metrics were derived from different ratios and combinations. Mean and standard deviations of all metrics were calculated for AD and NC groups. Whether the values are significant between AD and NC was calculated by independent samples t-test. Mean, standard deviation and p significance value of the metrics are given in Table 2 . The metrics were sorted in the table from the most significant to the most insignificant with respect to $\mathrm{p}$ value. 
Table 2: Mean, standard deviation and p significance values of the metrics(Öziç, 2018)

\begin{tabular}{lccccc} 
& \multicolumn{3}{c}{$\mathrm{AD}$} & $\mathrm{NC}$ & Stats \\
\cline { 2 - 6 } & Mean & $\mathrm{Std}$ & Mean & $\mathrm{Std}$ & $\mathrm{p}$ \\
\hline CSF/GM & 0.598 & 0.085 & 0.53 & 0.072 & $1,00 \mathrm{E}-06$ \\
(WM+CSF)/TIV & 0.586 & 0.022 & 0.57 & 0.016 & $2,00 \mathrm{E}-06$ \\
GM/TIV & 0.414 & 0.022 & 0.43 & 0.016 & $2,00 \mathrm{E}-06$ \\
(LV+CSF)/TIV & 0.28 & 0.034 & 0.253 & 0.033 & $7,00 \mathrm{E}-06$ \\
CSF/TIV & 0.246 & 0.025 & 0.227 & 0.024 & $9,00 \mathrm{E}-06$ \\
PRM/TIV & 0.754 & 0.025 & 0.773 & 0.024 & $9,00 \mathrm{E}-06$ \\
CSF/ PRM & 0.328 & 0.044 & 0.295 & 0.041 & $1,00 \mathrm{E}-05$ \\
CSF & 337 & 47.97 & 305.3 & 40.49 & $4,00 \mathrm{E}-05$ \\
LV/GM & 0.082 & 0.032 & 0.063 & 0.027 & 0.0002 \\
WM/CSF & $1 . N i s$ & 0.19 & 1.538 & 0.231 & 0.0002 \\
LV/ PRM & 0.045 & 0.017 & 0.035 & 0.015 & 0.0004 \\
LV/TIV & 0.034 & 0.012 & 0.027 & 0.011 & 0.0006 \\
LV & 46.44 & 19.77 & 36.01 & 15.58 & 0.0007 \\
LV/WM & 0.099 & 0.038 & 0.078 & 0.034 & 0.0009 \\
(GM+LV)/TIV & 0.447 & 0.019 & 0.456 & 0.013 & 0.0018 \\
LV/CSF & 0.135 & 0.044 & 0.115 & 0.041 & 0.0068 \\
WM/GM & 0.824 & 0.064 & 0.801 & 0.051 & 0.0149 \\
GM/ PRM & 0.549 & 0.019 & 0.556 & 0.016 & 0.018 \\
WM/ PRM & 0.451 & 0.019 & 0.444 & 0.016 & 0.018 \\
GM & 565.9 & 55.93 & 578 & 47.35 & 0.1706 \\
(WM+LV)/TIV & 0.374 & 0.018 & 0.37 & 0.017 & 0.2347 \\
(GM+CSF)/TIV & 0.66 & 0.017 & 0.656 & 0.018 & 0.2548 \\
WM/TIV & 0.34 & 0.017 & 0.344 & 0.018 & 0.2548 \\
TIV & 1369 & 132.9 & 1346 & 116 & 0.2861 \\
PRM & 1032 & 104.7 & 1041 & 96.57 & 0.5934 \\
WM & 466.2 & 55.73 & 463.2 & 53.19 & 0.7488 \\
\hline
\end{tabular}

The most significant value in $\mathrm{AD}$ and NC volume comparison is found in CSF/GM. GM/TIV and (WM+CSF)/TIV demonstrate a high degree of statistical significance after CSF/GM. GM, (WM+LV)/TIV, (GM+CSF)/TIV, WM/TIV, WM, TIV, PRM values are statistically insignificant. Since AD begins with forgetfulness, initial volumetric differences occur in memory-related brain regions on GM. In the literature, there are studies showing that volumetric losses and differences occur in GM and WM using voxel-based morphometry (G. Frisoni et al., 2002; Guo et al., 2010). But in this study, GM, WM, Parenchyma volume values alone gave meaningless results. Even if volumetric loss occurs in these regions, the different head size of each person gives meaningless results in volume comparisons. To overcome this problem, it is usually used by normalizing the measurements to a value. Normalization is performed by dividing the measured value by TIV or GM. Another approach is the proportion of measured values to each other (Ge et al., 2002; Orellana et al., 2016; Youn \& Hsiung, 2015). The aim of these approaches, even if the values measured in healthy people differ among themselves, their proportions to each other or global volumes will be similar. Therefore, patient-normal comparisons made using volume values will yield more objective results. Since there is the volumetric loss in GM and WM regions, CSF is filled to these regions. Since CSF increases too much, it shows a significant difference both alone and in TIV normalization. Significant differences were observed in LV volume alone and in TIV normalization as the LV region expands and the volume increase is very high (Bigler, 2015; Rababa'h, 2014). Since the skull does not shrink and the total brain volume does not change, it is an expected result that no significant difference TIV volume is observed. Since the PRM region is the sum of WM and GM, the change in this region significantly affected the statistical results in the combinations using PRM. As a result of the experiments, the normalization process to the TIV and Parenchyma regions mostly gives meaningful results. At the same time, the proportion of areas where volumetric loss is expected gives each other meaningful results. CSF/GM, (WM+CSF)/TIV, GM/TIV, (LV+CSF)/TIV, PRM/TIV, CSF/PRM, LV/ GM, WM/CSF, LV/PRM, LV/GM, WM/CSF, LV/PRM, LV/TIV, LV/WM, (GM+LV)/TIV, LV/CSF, WM/GM, GM/PRM, WM/PRM rates and normalization processes are the remarkable results of the study. 


\section{Conclusion}

Volumetric differences measured for AD in 3D T1-weighted MR images have a biomarker feature for the disease. In this study, global volumetric calculations were made with a model developed in AD and NC MR images, the ratios of regions to each other and the results of normalization processes were evaluated statistically. In the literature, although values such as GM / WM, GM / TIV are generally used for comparison, in this study has been determined that the ratios of other regions in the brain may give statistically significant results. Therefore, different rates determined in the study can be used as a biomarker for the disease. The different head sizes of each person can give misleading results for the analysis of regions alone in volumetric analysis studies. In this study, misleading points are statistically revealed and discussed after volumetric measurements. CSF/GM ratio has been proven in the study that it is an important and powerful biomarker for the disease. Manual interpretation of 3D MR images is a laborious, user-prone, time-consuming process. Computer-aided numerical methods can give more accurate and faster measurement results practically. With the measurement method used in this study, global brain regions can be measured quickly. In the future, it is an expected development in the field of medicine that such numerical methods are analyzed through the MR device or server and directed to the doctors as a pre-diagnosis in the form of a report.

\section{Kaynakça}

Ashburner, J. (2007). A fast diffeomorphic image registration algorithm. Neuroimage, 38(1), 95-113.

Ashburner, J., Barnes, G., Chen, C., Daunizeau, J., Flandin, G., Friston, K., . . Litvak, V. (2008). SPM8 manual. Functional Imaging Laboratory, Institute of Neurology, 41.

Association, A. s. (2019). 2019 Alzheimer's disease facts and figures. Alzheimer's \& Dementia, 15(3), 321-387.

Bigler, E. D. (2015). Structural image analysis of the brain in neuropsychology using magnetic resonance imaging (MRI) techniques. Neuropsychology Review, 25(3), 224-249.

Derneği, T. A. (2020). Türkiye'de 600bin aile Alzheimer Hastalı̆̆ ile Mücadele Ediyor. Retrieved from http://www.alzheimerdernegi.org.tr/haber/turkiyede-600-bin-aile-alzheimer-hastaligi-ile-mucadele-ediyor/

Dubois, B., Hampel, H., Feldman, H. H., Scheltens, P., Aisen, P., Andrieu, S., . . Blennow, K. (2016). Preclinical Alzheimer's disease: definition, natural history, and diagnostic criteria. Alzheimer's \& Dementia, 12(3), 292-323.

Fischl, B. (2012). FreeSurfer. Neuroimage, 62(2), 774-781.

Frisoni, G., Testa, C., Zorzan, A., Sabattoli, F., Beltramello, A., Soininen, H., \& Laakso, M. (2002). Detection of grey matter loss in mild Alzheimer's disease with voxel based morphometry. Journal of Neurology, Neurosurgery \& Psychiatry, 73(6), $657-664$.

Frisoni, G. B., Fox, N. C., Jack, C. R., Scheltens, P., \& Thompson, P. M. (2010). The clinical use of structural MRI in Alzheimer disease. Nature Reviews Neurology, 6(2), 67-77.

Ge, Y., Grossman, R. I., Babb, J. S., Rabin, M. L., Mannon, L. J., \& Kolson, D. L. (2002). Age-related total gray matter and white matter changes in normal adult brain. Part I: volumetric MR imaging analysis. American Journal of Neuroradiology, 23(8), 13271333.

Goto, M., Abe, O., Aoki, S., Hayashi, N., Miyati, T., Takao, H., . . Mori, H. (2013). Diffeomorphic Anatomical Registration Through Exponentiated Lie Algebra provides reduced effect of scanner for cortex volumetry with atlas-based method in healthy subjects. Neuroradiology, 55(7), 869-875.

Guo, X., Wang, Z., Li, K., Li, Z., Qi, Z., Jin, Z., . . Chen, K. (2010). Voxel-based assessment of gray and white matter volumes in Alzheimer's disease. Neuroscience letters, 468(2), 146-150.

Holland, D., Brewer, J. B., Hagler, D. J., Fennema-Notestine, C., Dale, A. M., Weiner, M., . . . Jagust, W. (2009). Subregional neuroanatomical change as a biomarker for Alzheimer's disease. Proceedings of the National Academy of Sciences, 106(49), 20954-20959.

Jenkinson, M., Beckmann, C. F., Behrens, T. E., Woolrich, M. W., \& Smith, S. M. (2012). Fsl. Neuroimage, 62(2), $782-790$.

Keller, S. S., \& Roberts, N. (2009). Measurement of brain volume using MRI: software, techniques, choices and prerequisites. $J$ Anthropol Sci, 87, 127-151.

Kempton, M. J., Underwood, T. S., Brunton, S., Stylios, F., Schmechtig, A., Ettinger, U., . . Frangou, S. (2011). A compreh ensive testing protocol for MRI neuroanatomical segmentation techniques: evaluation of a novel lateral ventricle segmentation method. Neuroimage, 58(4), 1051-1059.

Klein, A., Andersson, J., Ardekani, B. A., Ashburner, J., Avants, B., Chiang, M.-C., . . Hellier, P. (2009). Evaluation of 14 nonlinear deformation algorithms applied to human brain MRI registration. Neuroimage, 46(3), 786-802.

Kurth, F., Luders, E., \& Gaser, C. (2010). VBM8 toolbox manual. Jena: University of Jena.

Marcus, D. S., Wang, T. H., Parker, J., Csernansky, J. G., Morris, J. C., \& Buckner, R. L. (2007). Open Access Series of Imaging Studies (OASIS): cross-sectional MRI data in young, middle aged, nondemented, and demented older adults. Journal of cognitive neuroscience, 19(9), 1498-1507.

Mechelli, A., Price, C. J., Friston, K. J., \& Ashburner, J. (2005). Voxel-based morphometry of the human brain: methods and applications. Current medical imaging reviews, 1(2), 105-113.

MRIcro. (2020). Retrieved from https://people.cas.sc.edu/rorden/mricro/mricro.html

Orellana, C., Ferreira, D., Muehlboeck, J.-S., Mecocci, P., Vellas, B., Tsolaki, M., . . Simmons, A. (2016). Measuring global brain atrophy with the brain volume/cerebrospinal fluid index: normative values, cut-offs and clinical associations. Neurodegenerative Diseases, 16(1-2), 77-86.

Öziç, M., Ü. (2018). 3B Alzheimer MR Görütnülerinin Sınıflandırllmasında Yeni Yaklaşımlar. (Doktora Tezi), Selçuk Üniversitesi, Fen Bilimleri Enstitüsü, Konya, Türkiye 
Penny, W. D., Friston, K. J., Ashburner, J. T., Kiebel, S. J., \& Nichols, T. E. (2011). Statistical parametric mapping: the analysis of functional brain images: Elsevier.

Petrella, J. R., Coleman, R. E., \& Doraiswamy, P. M. (2003). Neuroimaging and early diagnosis of Alzheimer disease: a look to the future 1. Radiology, 226(2), 315-336.

Petropoulos, H., Sibbitt Jr, W. L., \& Brooks, W. M. (1999). Automated T2 quantitation in neuropsychiatric lupus erythematosus: a marker of active disease. Journal of Magnetic Resonance Imaging, 9(1), 39-43.

Rababa'h, Q. (2014). Intracranial volume Segmentation. (Master Thesis in Medicine), Örebro University,

Ridgway, G. (2020). Miscellaneous useful MATLAB scripts for SPM/VBM. Retrieved from http://www0.cs.ucl.ac.uk/staff/g.ridgway/vbm/get totals.m

Salat, D. H., Greve, D. N., Pacheco, J. L., Quinn, B. T., Helmer, K. G., Buckner, R. L., \& Fischl, B. (2009). Regional white matter volume differences in nondemented aging and Alzheimer's disease. Neuroimage, 44(4), 1247-1258.

Schuff, N., Woerner, N., Boreta, L., Kornfield, T., Shaw, L., Trojanowski, J., .. Initiative, D. N. (2009). MRI of hippocampal volume loss in early Alzheimer's disease in relation to ApoE genotype and biomarkers. Brain, 132(4), 1067-1077.

Selekler, K. (2010). Alois Alzheimer ve Alzheimer Hastalığı. Türk Geriatri Dergisi, 13(3), 9-14.

Talaraich, J., \& Tournoux, P. (1988). Co-planar stereotaxic atlas of the human brain. George Thieme, Stuttgard.

Vemuri, P., \& Jack, C. R. (2010). Role of structural MRI in Alzheimer's disease. Alzheimer's research \& therapy, 2(4), 23.

Villarreal, G., Hamilton, D. A., Petropoulos, H., Driscoll, I., Rowland, L. M., Griego, J. A., . . Brooks, W. M. (2002). Reduced hippocampal volume and total white matter volume in posttraumatic stress disorder. Biological psychiatry, 52(2), 119-125.

Youn, Y. C., \& Hsiung, G.-Y. R. (2015). A Voxel Based Morphometric Analysis of Longitudinal Cortical Gray Matter Changes in Progranulin Mutation Carriers At-Risk for Frontotemporal Dementia: Preliminary Study. Dementia and Neurocognitive Disorders, 14(4), 163-167. 